Kierkegaard Studies

Yearbook 2009

主

$W$
$\mathrm{DE}$
$\mathrm{G}$ 


\section{Kierkegaard Studies}

Edited on behalf of the

Søren Kierkegaard Research Centre

by Niels Jørgen Cappelørn and Hermann Deuser

Walter de Gruyter · Berlin · New York 


\section{Yearbook 2009}

Kierkegaard's Concept of Irony

Edited by

Niels Jørgen Cappelørn, Hermann Deuser and K. Brian Söderquist

Walter de Gruyter · Berlin · New York 


\section{Kierkegaard Studies}

Edited on behalf of the Søren Kierkegaard Research Centre

by Niels Jørgen Cappelørn and Hermann Deuser

Yearbook 2009

Edited by Niels Jørgen Cappelørn, Hermann Deuser

and K. Brian Söderquist

(2) Printed on acid-free paper which falls within the guidelines of the ANSI to ensure permanence and durability.

Bibliographic information published by the Deutsche Nationalbibliothek

The Deutsche Nationalbibliothek lists this publication in the Deutsche Nationalbibliografie; detailed bibliographic data are available in the Internet at http://dnb.d-nb.de.

ISBN 978-3-11-020788-0

ISSN (Internet) 1612-9792

(C) Copyright 2009 by Walter de Gruyter GmbH \& Co. KG, D-10785 Berlin All rights reserved, including those of translation into foreign languages. No part of this book may be reproduced or transmitted in any form or by any means, electronic or mechanical, including photocopy, recording or any information storage and retrieval system, without permission in writing from the publisher.

Printed in Germany 


\title{
From the Bibliomanic Nerd to the Resource File
}

\author{
A Historical Book Record as an Example of a Resource \\ for a Major Digital Edition ${ }^{1}$
}

By Karsten Kynde and Kim Ravn

\begin{abstract}
The project described here is carried out within the framework of the publication of Søren Kierkegaard's (1813-55) collected writings, Søren Kierkegaards Skrifter $(S K S)$. The edition consists of Kierkegaard's works, posthumous writings, journals, and papers, and appears in a printed version as well as a digital one. The printed version will eventually consist of 28 volumes with accompanying volumes of explanatory notes. The digital version $(S K S-E)$ will consist of additional texts, including the author's manuscripts and preparatory studies for the published works; it will also include various computer tools such as a search engine, concordances, indices of names, illustrations, maps, and other useful tools that we shall collectively call resource files. $S K S-E$ was presented on the internet in its initial version March 30, 2007, at http://sks.dk.
\end{abstract}

\section{Introduction to Søren Kierkegaards Skrifter}

\section{The Philological Object}

Søren Kierkegaard died on November 11, 1855. Five months later, on April 8, 1856, all his books were sold at a public auction in the apartment where he lived from 1852 until his death. A catalogue of his library was published for the auction, Catalogue of Dr. Søren Kierkegaards Collection of Books, ${ }^{2}$ and could be bought at the bookshop, like any other book. This

1 This paper was given at $14^{\text {th }}$ Biennial International Interdisciplinary Conference of the Society for Textual Scholarship at New York University, March 13-17, 2007.

2 The full title of the Catalogue: Fortegnelse over Dr. Sören Kierkegaards efterladte Bogsamling som bortsalges ved offentlig Auction Tirsdagen den 8de April 1856 og fölgende Dage i Kladeboderne Nr. 5-6. Alt imod Betaling til Procurator J. 
catalogue contained 2197 lots. ${ }^{3}$ During the auction, the prices on the lots and the names of the buyers were recorded in a handwritten sales record. Each page was divided into six columns, where the title of the books, catalogue numbers, and names of the buyers and prices were listed. Three columns were reserved for prices, designated in contemporary currency: Rixdollar, Mark and Shilling. Each page in the Catalogue corresponds to one page in the sales record. The collected items were published in 1967 by Hermann Peter Rohde, an art historian and librarian at The Royal Library in Copenhagen. He gave it the title The Auctioneer's Sales Record of the Library of Søren Kierkegaard. ${ }^{4}$ Rohde augmented the original Catalogue, adding information, first and foremost about who owned the books in 1967, and whether Kierkegaard had written in or in any other way left marks in the books. These could be notes or markings added as he read. Rohde also corrected errors in the catalogue text, e.g., the year of publication, numbers of volumes, etc. He also included information from various biographical documents. The result of Rohde's philological work is a single document composed of three texts: 1) the printed Catalogue, 2) the handwritten information from the sales record, and 3) Rohde's own corrections.

Kierkegaard's library was neither big nor small compared with other private libraries from his century. ${ }^{5}$ The Catalogue is divided into 29 sections separated with thin, horizontal lines. It is unknown whether these sections correspond to his own organization of the library. The various sections seem both logical and obvious considering that it is a private library, not a public one. Its primary purpose is to house books to be read, not loaned. The sections might thus reflect Kierkegaard's own organization of his books.

Rohde's edition of the Sales Record is based on bibliographical assumptions. This is clear from his inclusion of information about the fate of the books after the auction and from the long preface to his publication. In this preface that he titled "Søren Kierkegaard as a Collector of

Maag, Klodeboderne Nr. 101. The Catalogue was printed in 278 copies, a small number given the interest in Kierkegaard and his books per se.

3 Two appendices list 226 and 325 lots, resp. Within the scope of this project, these are not considered part of Kierkegaard's collection.

4 H. P. Rohde (ed.) Auktionsprotokol over Søren Kierkegaards bogsamling, incl. English translation by Helen Fogh, Copenhagen: The Royal Library 1967.

5 Niels Jørgen Cappelørn "Kierkegaard som bogkøber og bogsamler” in Niels J $\varnothing r-$ gen Cappelørn, Gert Posselt and Bent Rohde Tekstspejle, Esbjerg: Rosendahls Forlag 2002, pp. 105-219; pp. 114-119. 
Books," he examines Kierkegaard's library in search of rare books; he investigates bindings, the quality of the paper, etc., and he examines the library's character as a collection of books. The descriptions of the different bookbinders allows Rohde to include several biographical digressions about these anonymous craftsmen. Remarks on curious titles also give rise to similar digressions with references to Kierkegaard's journals. Rohde also investigates the bookseller's receipts, today located at the Kierkegaard Archive at the Royal Library in Copenhagen. These receipts make it possible for Rohde to add more titles to Kierkegaards library, titles of works that for various reasons were not present on the bookshelf when the Catalogue was compiled. The receipts makes it feasible to think that Kierkegaard in some way had used the book.

Since its publication in 1967, the Sales Record has been an important tool for Kierkegaard research, particularly for Kierkegaard philologists who write explanatory notes to Kierkegaard's text, i.e., the notes that make up 27 of the 55 volumes of SKS. In these explanatory notes, the Sales Record functions as a source for implicit and explicit quotations and allusions that characterize the Kierkegaardian text. His first book, for example, From the Papers of One Still Living [Af en endnu Levendes Papirer] (1838), is a reading of Hans Christian Andersen's (fictive) autobiography, Just a Fiddler [Kun en Spillemand] (1835). It is even more clear in his dissertation, On the Concept of Irony [Om Begrebet Ironie] (1841), where many of Plato's texts, recorded in Kierkegaard's own translation, are woven into his text without any quotation marks or anything else to indicate the source.

In other words, one can observe a significant change in the way the Sales Record is used in Kierkegaard scholarship. It was conceived as a bibliographical record but it has now become an intertextual map, as is the case in the explanatory notes in $S K S$, reflecting a more general change in the reading of Kierkegaard's work. This discussion is beyond the scope of this paper, however. If the Rohde Sales Record had been published with an eye to this (literary) reading of Kierkegaard's texts, the introduction would probably have been titled "Søren Kierkegaard as a Reader of Books."

As mentioned above, the philological object consists of three interrelated parts: The printed Catalogue, the handwritten information from the sales record, and Rohde's corrections and additions. All three parts will be included in a digital version. There are several reasons for this. The Catalogue is the core of the project. Rohde's corrections and additions, together with the handwritten information from the sales record, must be pre- 
served because of the history of reception. This additional information is now part of Kierkegaard reception, history and philological history. Finally, the corrections will increase the accuracy of a digital version. Rohde himself gives a good example in his preface: lot number 617-18 in the Catalogue mentions von Lavater as author of Physionomische Reisen; but Rohde can tell us that the name of the author is Musäus, who wrote a parody of von Lavater.

The project of establishing a text usually considers one text to be the base text, e.g., the first edition, and secondarily, it considers possible variants. But this text is complex or, to use the proper philological term, it is a contaminated text. Because we are not willing to dispense with any of the parts, the philological principles that apply to Kierkegaard's published works are not relevant when it comes to establishing a digital version of this text. However, obvious errors are to be corrected along the same lines as Rohde's. (Such a project has been undertaken at the Søren Kierkegaard Research Centre; the aim is to publish a printed English language version of the Catalogue. $)^{6}$ In a few cases, such a revision may prove impossible, given the rarity and age of the books in question. We have no intention, however, to allow the striving for completeness to hinder the project of a "revised version."

Finally, yet another way to supplement Kierkegaard's reading list should be mentioned. Whenever a literary reference or allusion is given by Kierkegaard, and whenever an explanatory note is written, the Catalogue is consulted. If the reference is not already listed there, it becomes a candidate for the supplement. The difference between this augmented list and an ordinary SKS bibliography is the (varying) certainty with which it can be shown that Kierkegaard actually read the book in question.

\section{Concluding Remarks}

The crucial point is the interchange between two sorts of texts, each of which have their own systematic aim. The Sales Record is a historically based, materialistic list of facts. This stands in contrast to the explanatory notes in $S K S$, which take their point of departure in a fractional bit of Kierkegaard's text (a lemma) and then attempt to locate a source from the in-

6 Katalin Nun "The Auction Catalogue of Kierkegaard's Library," to appear as vol. 18 of Jon Stewart et.al. Kierkegaard Research: Sources, Reception, and Resources, http://www.sk.ku.dk/KRSRR/. 
terlectual sphere that is considered to be well-known to Kierkegaard's contemporary reader. The practical aim of our project is to turn this information into a valuable tool for the Kierkegaard researcher as a digital resource file.

\section{The Practical Aspects of the Project}

\section{Phase 1: The Sales Record}

The first part of the practical part of the project is to create a digitally readable text file. This process is also known as scanning: A digital photocopy of the print is made and subsequently subjected to pattern recognition in order to identify each letter, also referred to as Optical Character Recognition (OCR). ${ }^{7}$ Then the file must be tagged. This means that the individual parts, e.g. headings, must explicitly be tagged as such. The most important elements with regard to the Sales Record are the Catalogue numbers and the corresponding bibliographic descriptions. In practice, this is done by putting tags into the text file that are distinguishable from other text, e.g.,

$<$ ktl id="1" $>1$ Biblia hebraica ...

It turns out that all Catalogue numbers start at the beginning of a line, meaning that this process can be done automatically, with relative ease. ${ }^{8}$ This is somewhat complicated by the fact that some of the records in the Catalogue have been allotted more than one number, e.g., 172930. In some cases, the auctioneer did not notice this and therefore used litra instead, e.g., 2057-2057a. In Rohde's version, numbers beyond the Catalogue, viz., those compiled from the bookseller's receipts, have been added to the original numbering system. Rohde suggests that one distinguish them with a "U," e.g.,

7 In our case an excellent scanning was made in 1991 by Stéphane Hogue of McGill University, Toronto, resulting in a WordPerfect file.

8 This sort of computer text processing benefits greatly from the use of regular expressions. I.e. the text is described by a Chomsky type 2 grammar. Knowledge of Chomsky's language hierarchy is not a prerequisite for the following description; suffice it to say that the above mentioned numbers can be expressed as follows: [0-9]+ Read: At line start, a character from the set of digits 0 through 9 appears one or more times. 
$<$ ktl id="U9" $>9$ Adler, A.P., Nogle Prædikener ...

\section{Phase 2: The SKS Explanatory Notes}

One reason for tagging the Catalogue numbers is to enable a digital reference, e.g., in the $S K S$ explanatory notes. In the $S K S$ digital edition we would expect such a reference to appear as a hypertext reference, activated by a mouse click. On the other hand, this requires that the digital version of the notes are tagged correspondingly, but because all such references are prefixed with a ktl., ${ }^{9}$ this task should prove straightforward, as well. This points to a formal discipline on the part of the editors of the $S K S$ notes, on which projects like this are dependent. The convention of identifying items from the outside collection with a "U" is also followed. ${ }^{10}$

Note: If the notes specify an interval, the units are indicated on both sides of the hyphen, e.g., 1551-1552. This rule is not always followed, but there are only a few exceptions. We obviously adopt this standard when tagging the Catalogue, so that if the right hand side of a hyphen has fewer decimals than the left hand, the right hand number is supplemented.

$<$ ktl id="1551 $-1552 ">1551-52$ Heiberg $\ldots$

One should also note that intervals do not necessarily refer to the same intervals in the Catalogue; thus, the second of the three(!) volumes of Zeitschrift für speculative Theologie may be designated: ktl. 354-357; vol. 2. But the same volume is sometimes referred to as $k t l$. 355. On the other hand, an interval may cover several separate entries in the Catalogue, e.g., ktl. 1507-1520, referring to Baggesen's works, individually compiled as 1507, 1508 together with the twelve volumes making up $1509-1520$.

We must utilize, in other words, the experience we have gained from phase 1, parsing the Catalogue, when we parse the references of the ex-

$9 k t l$. abbreviates "katalog," i.e. "catalogue." Curiously enough, the word "kata$\log$ " does not appear anywhere in the Danish title nor main text of the Catalogue. See the full title in note 3 .

10 Thus, the regular expression for catalogue references becomes: ktl. (U)?[0-9]+(-[0-9]+)?[a-z]? Read: ktl., space, possibly followed by " $U$ " and a space, one or more digits, sometimes a hyphen and digits, sometimes ending with a letter. 
planatory notes; hence, we can construct a formal reference to the Catalogue from any of the ktl. numbers in the notes; in the case of intervals, we refer to the first record.

A special challenge for the project is the possible occurrence of errors within the notes. Generally, we must assume that a reference that is quoted verbatim from the Catalogue is correct. The variants above, i. e., intervals referring to individual numbers or individual numbers referring to an interval, can and should be unified. Conversely, it turns out that the intervals that refer to a yet smaller interval than those listed in the Catalogue are always typographical errors. The same obviously goes for intervals on the right hand side (even after having been supplemented with the missing units) that are less than the left hand side.

\section{Phase 3: The Sales Record Revisited}

At this point in the project, an idea presented itself: The references from the notes to the Catalogue are self evident, but this does not provide the researcher with very much new information. It is interesting that the referenced work is actually present in the Catalogue, but reading the source itself only satisfies the suspicious reader. References in the opposite direction could prove much more valuable: Where in the explanatory notes is this book mentioned or referenced? The answer constitutes a map of Kierkegaard's authorship showing his interest in the relevant author or theme. In this way, we treat the authorship backwards, in a sense, or perhaps sideways, and this may be able to shed light on the impact of Goethe, Hegel, etc., its character and the time when it occurred. So, here we begin again:

The Catalogue, already tagged, must be re-parsed, this time based on the experience obtained from the notes in Phase 2, and numbers that are actually referred to. Take interval problems into account: One single reference may in fact cover several references when one moves in the opposite direction. This is an odd application of the computing concept called a multi pass algorithm, a recognition of the fact that you cannot take action on a text before having read all the text once. This concept is best explained by a joke: 
Little old lady, riding a bus: "Little boy, can you tell me how I can get off at Pasadena Street?"

Little boy: "Just watch me, and get off two stops before I do."

(The joke is that the little boy gives a two-pass algorithm.) ${ }^{11}$

\section{Miscellaneous Details}

In his remarks to his scanned version of the Sales Record, Stéphane Hogue says: "The various indexes or 'registers' are not included in this package because the ease with which one can now search the database with the aid of a computer makes them superfluous." ${ }^{12}$ This may be so; however, indices compiled by a human show their importance by introducing a normalization of author names that is otherwise absent. E.g., René Descartes may be rendered Cartesius at times. Therefore one cannot be sure that one has found all references to an author merely by searching textually for his name; in the index, however, both will occur under the entry, Descartes, $R$. Authors with pseudonyms will be indicated with both names. We have scanned the index as well, but we will not render it as an alphabetical list; we include each name as an attribute of each of the numbers to which it belongs (which is given in the index). Doing so, one inevitably finds some errors. For example, J. E. Erdmann is not really represented with almost 400 titles, as it would appear from the figures 479-844; this is, in fact, a metathesis for $479-484$.

A companion source for the Rohde edition is the above-mentioned bookseller's reciepts. Prior to the work with the Sales Record, Rohde had compiled these receipts and published them in the Royal Library publication Fund og Forskning [Results \& Research] in $1961,{ }^{13}$ to which he frequently refers. This material has also been scanned and made accessible, so that the reader of the digital $S K S$ will eventually be able to follow Rohde back to the origin of his sources.

11 D. E. Knuth The Art of Computer Programming, vol. 1, Reading, Massachusetts: Addison-Wesley 1968, chp.1.4.2.

12 See note 8.

13 H. P. Rohde "Søren Kierkegaard som bogsamler" in Fund og Forskning VIII, Copenhagen: The Royal Library 1961, p. 79, annex VI-VIII. 